\title{
Effect of the celexoxib in microscopic changes of the esophageal mucosal of rats induced by esofagojejunostomy
}

\section{Efeito do celecoxibe nas alterações microscópicas da mucosa esofágica de ratos causadas por esofagojejunostomia}

\author{
Austry Ferreira de Lima, ACBC-AL; ;aercio Gomes Lourenço, TCBC-SP2; Délcio Matos²; Célıo Fernando de Sousa Rodrigues³
}

A B S T R A C T

\begin{abstract}
Objective: To evaluate the protective effect of celecoxib in the esophageal mucosa in rats undergoing esofagojejunostomy. Methods: Sixty male Wistar rats from the vivarium of the University of Health Sciences of Alagoas were used for the experiment. The animals were divided into four groups: Group I, 15 rats undergoing esofagojejunostomy with the use of celecoxib postoperatively; Group II, 15 rats undergoing esofagojejunostomy without the use of celecoxib; Group III, 15 rats undergoing celiotomy with bowel manipulation; and Group IV, 15 rats without surgery and using celecoxib. The observation period was 90 days. After the death of the animals, the distal segment of the esophagus was resected and sent for microscopic analysis. Results: esofagojejunostomy caused macroscopic and microscopic esophagitis. Esophagitis was equal in both groups I and II. In groups III and IV esophageal lesions were not developed. Conclusions: celecoxib had neither protective nor inducing effect on esophagitis, but had a protective effect on dysplasia of the animals of group I.
\end{abstract}

Key words: Esophagitis, peptic. Epithelium/histology. Inflammation. General surgery. Rats, Wistar

\section{INTRODUCTION}

$T^{\mathrm{n}}$ he gastroesophageal reflux disease (GERD) has great medical and social importance due to its high and increasing incidence and to its symptoms of varying intensity, manifested by prolonged time and often decreasing patients' quality of life ${ }^{1}$. It is a common condition that affects around $20-50 \%$ of adults in Western countries $^{2}$.

Isolated heartburn was observed in $17.8 \%$ of adults suffering from this disease. In the West, the incidence of GERD is estimated between 10 and 20\% in adults ${ }^{3}$.

GERD is defined as a condition that develops when the reflux of stomach contents into the esophagus causes symptoms and / or complications ${ }^{4,5}$. The prevalence of GERD was evaluated and the weekly occurrence of symptoms of heartburn and acid regurgitation was observed. These symptoms were present in approximately $2 \%$ of children between three and nine years old and between $5 \%$ and $8 \%$ in children between ten and 17 years.

In the U.S., more than $50 \%$ of adults reported heartburn at least once a week and one fourth made use of antiacid medication at least three times a week. In
Brazil, in a population study with national coverage, heartburn (once a week), was present in $4.6 \%$ of the sample. When the incidence of heartburn was once or twice a week, prevalence was $7.3 \%$. It is estimated that approximately $12 \%$ of the population has GERD, without including those with atypical manifestations, which should certainly increase this number ${ }^{6}$.

In 1893, the German chemist Felix Hoffman discovered the anti-inflammatory agent aspirin, widely prescribed and used worldwide. Its mechanism of action was elucidated only in 1971, when John Vane proposed that anti-inflammatory drugs, like aspirin, suppress inflammation by inhibiting the enzyme cyclooxygenase (COX), thereby preventing the synthesis of prostaglandins 7. COX catalyzes prostaglandins, also known as Prostaglandin Synthetase or Prostaglandin Endoperoxide Synthase. These prostaglandins were isolated in 1976 and cloned in 1988. In 1991 a gene encoding a second isoform of the enzyme was identified, then denominated cyclooxygenase-2 (COX-2). It is known nowadays that both genes express two very similar distinct isoforms of the enzyme: cyclooxygenase-1 (COX1) and cyclooxygenase-2 (COX-2). The two isoforms have similar protein structures and catalyze essentially the same reaction ${ }^{8-13}$.

1. Post-Graduation Program in Surgical Gastroenterology - Escola Paulista de Medicina (UNIFESP); 2. Department of Surgical Gastroenterology - Escola Paulista de Medicina (UNIFESP); 3. Department of Morphology, Universidade Federal de Alagoas (UFAL). 
The combination of these agents produced a new generation of anti-inflammatory drugs (selective COX2 inhibitors), called the coxibs ${ }^{14,15}$.

More recently, new motivations for clinical use and research were found with the description of a third cyclooxygenase variant, called COX3 ${ }^{16}$. Studies have demonstrated that the concentration of COX-2 is elevated both in esophagitis, in Barrett's esophagus and in esophageal adenocarcinoma ${ }^{17-19}$

Although substances such as COX2 and others have important roles in several known anti-inflammatory events, the pathogenesis of gastroesophageal reflux disease in is still unknown. On an induced reflux esophagitis model in rats, there was a significant increase in the expression of $\mathrm{COX} 2$, indicating its important role in the pathogenesis of esophagitis 20 .

Celecoxib is a drug with anti-inflammatory and analgesic action. Despite its effect, there is still lack of mainly pharmacological studies investigating its actual molecular and cellular actions, as well as its interference in cellular metabolism, oxidative stress and the expression of proteins linked in the development of certain diseases. This research aimed to evaluate whether celecoxib exerts a protective role on the esophageal mucosa of rats subjected to esofagojejunostomy.

\section{METHODS}

From January 2009 to December 2010, we studied 60 animals, aged between three and four months, average weight of $350 \mathrm{~g}$ and acclimated to the vivarium conditions at the State University of Health Sciences of Alagoas - UNCISAL. The project was approved by the Ethics Committee of UNIFESP / EPM with number 1872/0.

The animals were housed, up to three animals per cage, and were fasted for 12 hours before the operation. The observation period for the four groups was 90 days. Celecoxib was administered orally at a dose of $10 \mathrm{mg} / \mathrm{kg} /$ day, in agreement with other studies $21-23$

The animals were divided into four groups: Group I, 15 rats undergoing esofagojejunostomy and receiving celecoxib postoperatively; Group II, 15 rats submitted to esofagojejunostomy without the use of celecoxib; Group III, 15 rats undergoing celiotomy with bowel loops manipulation; Group IV, 15 rats without esofagojejunostomy and receiving celecoxib (Table 1).

The anesthetic technique was by intraperitoneal injection of ketamine hydrochloride (80 to $100 \mathrm{mg} / \mathrm{kg}$ ), associated with $10 \mathrm{mg} / \mathrm{kg}$ of xylazine for relaxation ${ }^{24}$. All animals were operated under aseptic, acclimated conditions and fed ad libitum from the third postoperative day on.

The animals were submitted to antisepsis of the abdominal wall with polyvinyl iodine polirridone and asepsis. The median celiotomy was from the xiphoid appendix to the middle third of the abdominal wall, including the skin,
Table 1 - Distribution of rats according to the procedure and drug use.

\begin{tabular}{lccr}
\hline Group & Total & Operation & Drug \\
\hline I & 15 & $100 \%$ & $100 \%$ \\
II & 15 & $100 \%$ & $0 \%$ \\
III & 15 & $100 \%$ & $0 \%$ \\
IV & 15 & $0 \%$ & $100 \%$ \\
\hline
\end{tabular}

subcutaneous tissue, muscle-aponeurotic plane and parietal peritoneum. In groups I and II we proceeded to display, repair and opening of $0.5 \mathrm{~cm}$ of jejunum $10 \mathrm{~cm}$ distally from the duodenojejunal junction. The dissection of the distal esophagus was carried out by the release of the hepatic ligaments. With a magnifying glass with a $10 x$ range, we held a $1.0 \mathrm{~cm}$ longitudinal opening in the esophagus and performed a lateral-lateral esofagojejunostomy (Figure 1) with a running suture of 7-0 Prolene with atraumatic needle; we then proceeded immediately to the closing of the muscle-aponeurotic plane with chrome 5-0 catgut and the skin with 5-0 nylon, both with running sutures.

In groups I and IV $10 \mathrm{mg} / \mathrm{kg} /$ day of Celecoxib were administered orally, in gavage, using a $1 \mathrm{ml}$ syringe, from the third day after surgery until the day they were euthanized.

All animals were maintained post-operatively under the same environmental conditions. Postoperative analgesia was made with dipyrone $20 \mathrm{mg}$ by gavage for three days. In the first 24 hours the animals received only water ad libitum in a solution of $5 \%$ glucose. The extruded Labina, a proper chow for this type of animal, was initiated from the third day. The animals were weighed fortnightly.

At the end of 90 days the animals were euthanized with a thionembutal intraperitoneal injection

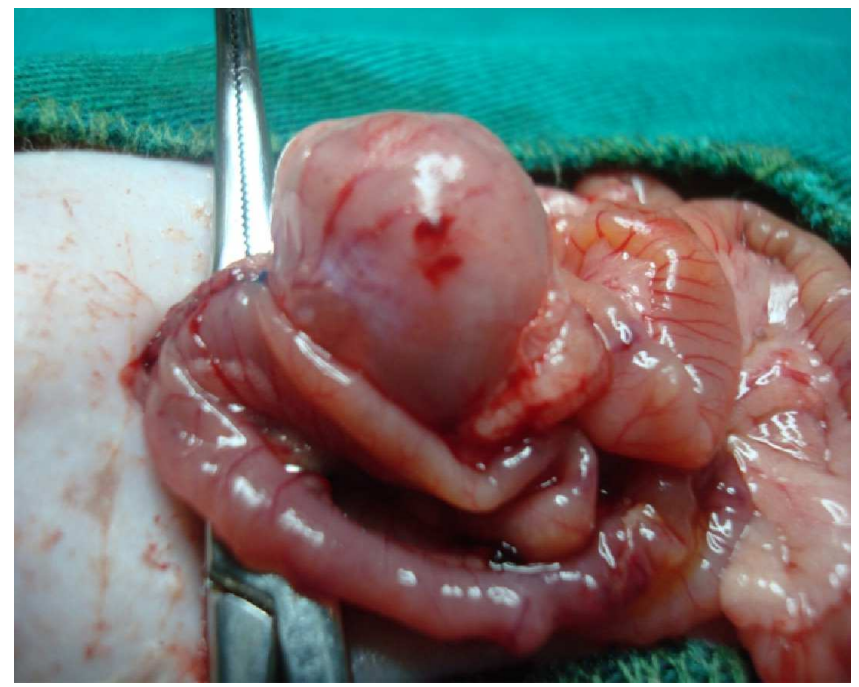

Figure 1 - Laterolateral esophagojejunal anastomosis. 
at a dose of $50 \mathrm{mg} / \mathrm{kg}$ followed by an intracardiac injection of potassium chloride. The specimens were obtained (Figure 2) and forwarded to the Department of Pathology, Maceio Holy Home of Mercy, for histopathological examination.

Macroscopic analysis was performed by measuring the specimens, followed by longitudinal cuts in their entire length, dehydration, paraffinization, histological sections stained by hematoxylin and eosin, followed by analysis with optical microscope with 10x and 40x magnifications, made by two pathologists, without any knowledge of the material between them.

Given the findings of our study, two statistical evaluations were used: Fisher's exact test in Groups I and $I$, to assess the use or not of the drug, and the relative risk, also applied to Groups I and II, to evaluate high and low-grade dysplasias.

\section{RESULTS}

Esophagitis with dysplasia was found in 28 animals, 13 having high-grade dysplasia and 15 low-grade. The following microscopic changes were present in group I: chronic esophagitis with high-grade dysplasia in three animals (Figure 3), chronic esophagitis with low-grade dysplasia in ten animals and adenocarcinoma in two. In group II we found: chronic esophagitis with high-grade dysplasia in ten animals and chronic esophagitis with lowgrade dysplasia in five. As for the outcome high-grade dysplasia, group I had a relative risk of 0.29 (71\% protective effect - calculated by the ratio of incidences) when compared with group II. No microscopic changes of the esophageal mucosa were found in rats in groups III and IV.

\section{DISCUSSION}

Surgical research with laboratory animals has expanded in recent decades due to the better support anesthetic techniques, the sophistication of the infrastructure equipment for continuous intraoperative monitoring and an incessant search for models that reproduce morbid conditions of the human species. The main focus of this research has been to improve the knowledge of the pathophysiological mechanisms of diseases, increase therapeutic trials with new drugs, study biological markers, with prospects of applicability in humans.

Of the 86 animals studied, 26 (30.2\%) died before the stipulated time for research, which we regard as early deaths, with the following causes: three cases of intracavitary abscess, eight cases of aspiration, three cases of anastomotic stenosis and in 12 cases in which we could not find the cause.

All animals were autopsied after death. Where the cause of death was not found, the hypothesis that the

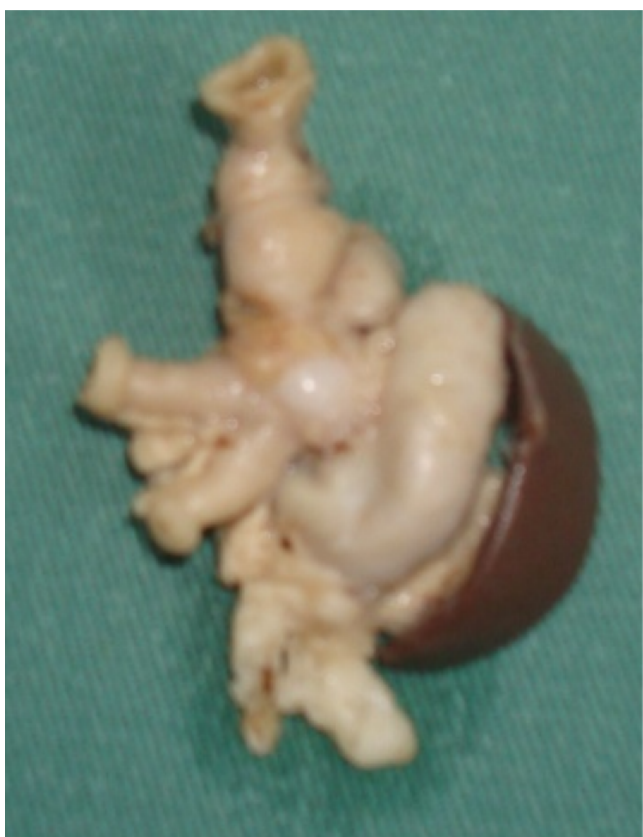

Figure 2 - Specimen for histopathology: dilated esophagus, afferent and efferent loops, stomach, spleen and esophagojejunal anastomosis.

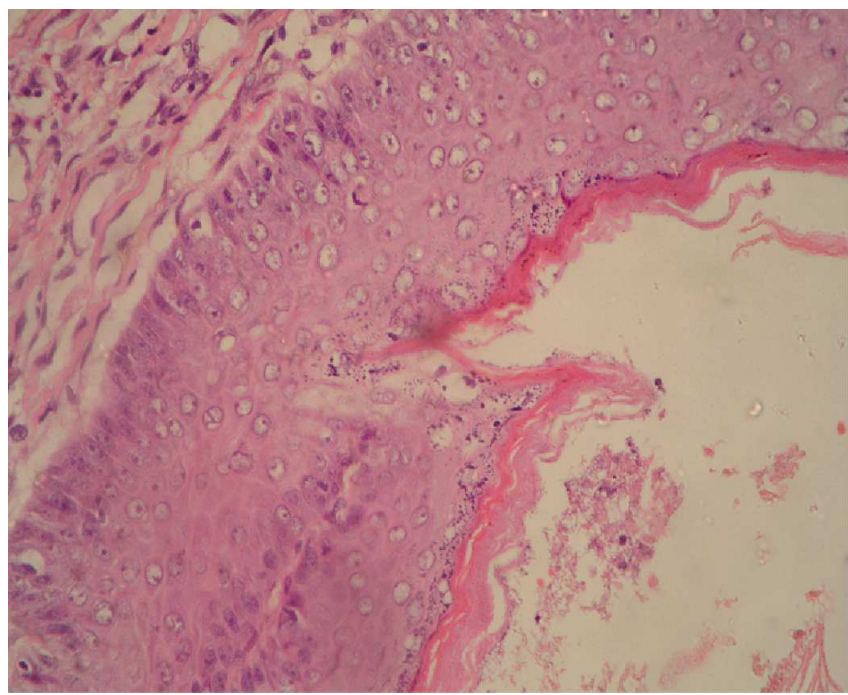

Figure 3 - Esophagitis with high-grade dysplasia.

anesthetic, muscle relaxant, or even dipyrone, had been the cause of death has not been ruled out, since xylazine, although inducing a rapid and effective sedation and analgesia, can have harmful effects such as hypotension and bradycardia.

Histopathological results confirmed the presence of esophagitis with different degrees of dysplasia in 28 animals, 13 with high-grade dysplasia and 15 with lowgrade, and two cases of invasive adenocarcinoma. Regarding dysplasia, the diagnosis was based on cytologic and structural alterations proposed by Montgomery in 2002, an algorithm that distinguishes epithelial in low or high grade dysplasia. The algorithm is based on the main histological 
features found in Barrett's esophagus ${ }^{25}$. The cluster of glands varied sizes and shapes with branches or cribiform arrangements is an important architectural change. Epithelial maturation is a key attribute for the diagnosis of dysplasia ${ }^{25,26}$. Dysplasia should be examined by comparing the cells in the deeper portions of the mucosa with surface ones. The cytological features belonging to the Montgomery algorithm should be analyzed under the microscope in the largest magnifications. These cells should display discrete atypia by increased volume of their nuclei. The polarity of the cells is also part of the Montgomery algorithm to be studied. The polarity is normal when the nuclei are arranged in parallel, with the largest axis perpendicular to the basement membrane, the loss of polarity of nuclei being a characteristic morphological attribute of high-grade dysplasia.
A study with rats subjected to esofagojejunostomy using a COX2 inhibitor, rofecoxib, showed no esophageal mucosal protection. The authors claimed that protection does not exist in severe injuries and suggested conducting studies with models of less severe esophagitis ${ }^{27}$. Yet, according to these authors ${ }^{27}$, neither rofecoxib nor vitamin $C$ had a protective effect against esophagitis in this reflux model. This seems the most plausible answer to the result of our research, taking into account also that Murphy et al. ${ }^{27}$ exposed the esophageal mucosa of their animals for only six weeks, whereas in ours the exposure lasted for 12 weeks.

In conclusion, our study showed that celecoxib had neither a protective nor an inducing effect on esophagitis, but showed a protective effect in dysplasias of the animals of group I.

\title{
R E S U M O
}

\begin{abstract}
Objetivo: avaliar o efeito do celecoxibe como função protetora na mucosa esofágica, em ratos machos Wistar, submetidos à esofagojejunostomia. Métodos: sessenta animais oriundos do biotério da Universidade de Ciências da Saúde de Alagoas foram utilizados para o experimento. Os animais foram distribuídos em quatro grupos: Grupo l, 15 ratos que foram submetidos à esofagojejustomia e que utilizaram o celecoxibe no pós-operatório, Grupo II, 15 ratos submetidos à esofagojejunostomia sem uso de celecoxibe, Grupo III, 15 ratos submetidos à celiotomia com manipulação de alças, e Grupo IV, 15 ratos sem cirurgia e que utilizaram celecoxibe. O período de observação foi de 90 dias. Após a morte dos animais, o seguimento distal do esôfago foi ressecado e enviado para análise macro e microscópicas. Resultados: a esofagojejunostomia causou esofagite macro e microscópica. A esofagite foi igual tanto no grupo I quanto no II. Nos animais dos grupos III e IV não foram desenvolvidas lesões esofagianas. Conclusões: o celecoxibe não teve efeito protetor nem indutor nas esofagites, mas obteve efeito protetor nas displasias dos animais do grupo 1 .
\end{abstract}

Descritores: Esofagite de refluxo. Epitélio/histologia. Inflamação. Cirurgia. Ratos Wistar.

\section{REFERENCES}

1. Nasi A, Moraes-Filho JPP, Zilberstein B, Ceconnello I, GamaRodrigues J. Doença do refluxo gastroesofágico: comparação entre as formas com e sem esofagite, em relação aos dados demográficos e as manifestações sintomáticas. Arq Gastroenterol. 2001:38(2):109-15.

2. Labenz J, Jaspersen D, Kulig M, Leodolter A, Lind T, Meyer-Sabellek $W$, et al. Risk factors for erosive esophagitis: a multivariate analysis based on the ProGERD study initiative. Am J Gastroenterol. 2004;99(9):1652-6.

3. Dent J, El-Serag HB, Wallander MA, Johansson S. Epidemiology of gastro-oesophageal reflux disease: a systematic review. Gut. 2005;54(5):710-7.

4. Nelson SP Chen EH, Syniar GM, Christoffel KK. Prevalence of symptoms of gastroesophageal reflux during childhood: a pediatric practice-based survey. Pediatric Practice Research Group. Arch Pediatric Adolesc Med. 2000:154(2):150-4

5. Vakil N, van Zanten SV, Kahrillas P, Dent J, Jones R; Global Consensus Group. The Montreal definition and classification of gastroesophageal reflux disease: a global evidence-based consensus. Am J Gastroenterol. 2006:101(8):1900-20.

6. Moraes-Filho J, Cecconello I, Gama-Rodrigues J, Castro L, Henry MA, Meneghelli UG, et al. Brazilian consensus on gastroesophageal reflux disease: proposals for assessment, classification and management. Am J Gastroenterol. 2002;97(2):241-8.
7. Vane JR. Inhibition of prostaglandin synthesis as a mechanism of action for aspirin-like drugs. Nat New Biol. 1971:231(25):232-5.

8. DeWitt $\mathrm{DL}$, Smith WL. Primary structure of prostaglandin $\mathrm{G} / \mathrm{H}$ synthase from vesicular gland determined from the complementary DNA sequence. Proc Natl Acad Sci U S A. 1988;85(5):1412-6. Erratum in: Proc Natl Acad Sci U S A. 1988;85(14):5056

9. Kujubu DA, Fletcher BS, Varnum BC, Lim RW, Herschman HR. TIS10, a phorbol ester tumor promoter-inducible mRNA from Swiss $3 T 3$ cells, encodes a novel prostaglandin synthetase/ciclooxygenase homologue. J Biol Chem. 1991;266(20):12866-72.

10. Xie WL, Chipman JG, Robertson DL, Erikson RL, Simmons DL. Expression of a mitogen-responsive gene encoding prostaglandin synthase is regulated by mRNA splicing. Proc Natl Acad Sci U S A. 1991:88(7):2692-6

11. Crofford LJ. COX-1 and COX-2 tissue expression: implications and predictions. J Rheumatol Suppl. 1997;49:15-9.

12. Vane JR, Bakhle YS, Botting RM. Ciclooxigenase 1 and 2. Annu Rev Pharmacol Toxicol. 1998;38:97-120.

13. Kulkarni SK, Jain NK, Singh A. Cyclooxigenase isoenzymes and newer therapeutic potential for selective COX-2 inhibitiors. Methods Find Exp Clin Pharmacol. 2000;22(5):291-8.

14. FitzGerald GA, Patrono C. The coxibs, selective inhibitors of cyclooxigenase-2. N Engl J Med. 2001:345(6):433-42.

15. Carvalho WA, Lemonica L. Mecanismos celulares e moleculares da dor inflamatória. Modulação periférica e avanços terapêuticos. In: Braz JRC, Castiglia YMM, organizadores. Temas de 
anestesiologia. Curso de Graduação em Medicina. $2^{\text {a }}$ ed. São Paulo: Artes Médicas; 2000. p. 265-80.

16. Chandrasekharan NV, Dai H, Roos KL, Evanson NK, Tomsik J, Elton TS, et al. COX-3, a cyclooxigenase-1 variant inhibited by acetaminophen and other analgesic/ antipyretic drugs: cloning, structure, and expression. Proc Natl Acad Sci U S A. 2002:99(21):13926-31.

17. Zimmermann KC, Sarbia M, Weber AA, Borchard F, Gabbert HE, Schrör K. Cyclooxygenase-2 expression in human esophageal carcinoma. Cancer Res. 1999;59(1):198-204.

18. Zhang F, Altorki NK, Wu YC, Soslow RA, Subbaramaiah K, Dannenberg AJ. Duodenal reflux induces cyclooxygenase- 2 in the esophageal mucosa of rats: evidence for involvement of bile acids. Gastroenterology. 2001;121(6):1391-9.

19. Kaur BS, Khamnehei N, Iravani M, Namburu SS, Lin O, Tradafilopoulos G. Rofecoxib inhibits cyclooxygenase 2 expression and activity and reduce cell proliferation in Barrett's esophagus. Gastroenterology. 2002;123(1):60-7.

20. Hayakawa T, Fujywara $Y$, Hamaguchi M, Sugawa T, Okuyama M Sasaki $\mathrm{E}$, et al. Roles of cyclooxigenase 2 and microsomal prostaglandin E synthase 1 in rat acid reflux oesophagitis. Gut. 2006;55(4):450-6.

21. Hu PJ, Yu J, Zeng ZR, Leung WK, Lin HL, Tang BD, et al Chemoprevention of gastric cancer by celecoxib in rats. Gut. 2004;53(2):195-200.

22. Yu J, Tang BD, Leung WK, To KF, Bai AH, Zeng ZR, et al. Different cell kinetic changes in rat stomach cancer after treatment with celecoxib or indomethacin: implications on chemoprevention. World J Gastroenterol. 2005:11(1):41-5.
23. Wu YL, Fu SL, Zhang YP, Qiao MM, Chen Y. Cyclooxigenase-2 inhibitors suppress angiogenesis and growth of gastric cancer xenografts. Biomed Pharmacother. 2005;59 Suppl 2:S289-92.

24. Flecknell PA. Laboratory animal anaesthesia: a practical introduction for research workers and technicians. $2^{\text {nd }}$ ed. San Diego: Academic Press; 1996.

25. Montgomery E. Update on grading dysplasia in Barrett's esophagus. Pathol Case Reviews. 2002;7(1):35-42.

26. Haggitt RC. Barrett's esophagus, dysplasia and adenocarcinoma. Hum Pathol. 1994:25(10):982-93

27. Murphy JO, Ravi N, Byrne PJ, McDonald GS, Reynolds JV. Neither antioxidants nor COX-2 inhibition protect against esophageal inflammation in an experimental model of severe reflux. J Surg Res. 2007;142(1):20-7

Received on $02 / 01 / 2013$

Accepted for publication 15/03/2013

Conflict of interest: none.

Source of funding: none.

Address for correspondence:

Austry Ferreira de Lima

E-mail: austrylima@uol.com.br 